УДК 24-17

АБАЕВА Любовь Лубсановна - доктор исторических наук, профессор; главный научный сотрудник отдела философии, культурологии и религиоведения Института монголоведения, буддологии и тибетологии СО РАН (670047, Россия, Республика Бурятия, г. Улан-Удэ, ул. Сахьяновой, 6; lиваabaeva@mail.ru)

\title{
ФЕНОМЕН ЗЕМЛИ В КОНТЕКСТЕ ТРАДИЦИОННЫХ РЕЛИГИОЗНЫХ ВОЗЗРЕНИЙ МОНГОЛЬСКИХ НАРОДОВ В ВЕКТОРЕ АДАПТАЦИИ БУДДИЙСКИХ ТЕОРИЙ И ПРАКТИК: СРАВНИТЕЛЬНЫЙ АНАЛИЗ
}

\begin{abstract}
Аннотация. В статье на материале монгольских народов рассматривается феномен Земли как мифотворческий, мифопоэтический и мировоззренческий образ, который фиксируется в их космогонических и космогенетических представлениях, зафиксированных в системе взглядов на объективный и субъективный миры. Космогонические представления монгольских народов отражают синхронные аспекты их представлений о структуре мира, его устройстве, взаимосвязях и функциях. Космогонические и космогенетические мифы монгольских народов диахроничны, т.к. концентрируются на общей идее возникновения Вселенной, ее уникальности, эволюции, а также проблеме пространства и времени, происхождения Земли, небесных тел, человека, животных и растительного мира. В контексте космогенетических представлений наиболее популярен и характерен миф о дуальной организации Неба и Земли (ТэнгэрГазар дэлхий, Умай). Затронуты также некоторые буддийские идеи и практики, связанные с феноменом Земли.
\end{abstract}

Ключевые слова: феномен Земли, монгольские народы, традиционные космогонические и космогенетические представления, буддийские дискурсы, сравнительный анализ

B традиционных социокультурных традициях и религиозных культурах многих народов мира феномен Земли как мифотворческий, мифопоэтический и мировоззренческий образ фиксируется в их космогонических и космогенетических представлениях, системе взглядов как на объективный, так и на субъективный миры. «Современные исследователи мифологии коренным образом отличаются во взглядах на природу, круг содержания и значение древних мифов, - считает С.М. Крамер. - Некоторые смотрят на них как на плоские, суеверные сказки, малоинтересные по своему умственному и духовному содержанию... Диаметрально противоположна точка зрения ученых, которые полагают, что мифы древних представляют одно из глубочайших достижений человеческого духа, вдохновенное творение талантливых мифотворческих умов, не испорченных модным научным подходом аналитического мышления и поэтому открытых для глубоких космических прозрений, сокрытых от современного думающего человека с его сковывающими дефинициями и бесплодной, бездушной логикой» [Крамер 1977: 125; Мифологии... 1977: 5]. Особое место среди множества мифотворческих жанров занимают, на наш взгляд, космогонические мифы и космологические представления, поскольку они непосредственно затрагивают пространственно-временные параметры Вселенной, в которых находит себя то или иное конкретное сообщество людей. Космологические представления монгольских народов, впрочем, как и всех народов мира, отражают синхронные аспекты его структуры и устройства, взаимосвязи и функции в контексте конкретного мифоисторического периода. Космогонические и космогенетические мифы монголосферы более диахронны, т.к. концентрируются на общей 
идее возникновения Вселенной, ее уникальности, эволюции, а также содержат развитые идеи пространства и времени, происхождения Земли, небесных светил, человека, животных и растительного мира. Для монгольских космогонических мифов наиболее популярны и характерны мифы «приподнятия» Неба над Землей, что свидетельствует о присутствии более архаичных дуальных представлений: верх - низ, небо - земля, правое - левое, мужское - женское, добро - зло и т.д.

Исследование традиционного мировоззрения монгольских народов, анализ сложившихся в глубине веков традиционных взглядов, традиционной системы миропонимания и определения своего места в микромире - монголосфере, а также в макромире - мире вокруг монгольской метаэтнической общности, представляется нам очень важным и актуальным с точки зрения уникальности феномена Земли. Традиционное мировоззрение монгольских народов (Хамаг Монгол) выработало своеобразные представления. Картина мира, созданная в результате эволюции монгольской метаэтнической общности - это достаточно целостная и упорядоченная система, в которой важное место занимают такие категории, как время и пространство [Абаева 2017]. Земля в культурах разных народов как одна из основных мифологем мироздания [зем (общеслав.) - пол, низ ${ }^{1}$; умай, этуген (тюрк., монг., бурятск.) - пещера, материнское лоно, праматерь; газар дэлхий (монг.) - широкая земля, сакральная пара Неба] в основном выступала как архетипический образ матери-земли. Согласно современным космогоническим представлениям, Земля образовалась около 4,54 млрд лет назад «путем гравитационной конденсации из рассеянного в околосолнечном пространстве газопылевого вещества, содержащего все известные в природе химические элементы» ${ }^{2}$. В космогонических мифах монгольских народов о феномене Земли, а также в их картине мира, мировосприятии и миропонимании не фиксируется тот факт, что Земля имеет концентрически расположенные слои - ядро, окруженное мантией, которую окружает земная кора (иногда трактуется как твердая). Однако их традиционные представления о географической, или ландшафтной оболочке Земли достаточно обширны. Параметры поверхности Земли - гидросфера и атмосфера - кодифицируются многочисленными обрядами, ритуалами и культами почитания небесных явлений и водных территорий. Гравитационные, магнитные и электрические возможности Земли как сферы их обитания в мифологии монгольских народов представлены в почитании категории неперсонифицированного космического начала матери-земли (Умай - тюрк., монг.; Этугэн-эхэ - монг.). При этом в их добуддийских представлениях Земля как космическое женское начало и плодородящее женское чрево ассоциировалась, как правило, в паре с Небом (Хухэ Мунхэ Тэнгэри). Будучи представителями кочевой цивилизации, монголы достаточно хорошо представляли себе и небесную сферу. Солнце почиталось ими как космическое мужское, а Луна - как космическое женское начало. О гравитационном притяжении Земли, которое удерживает на околоземной орбите Луну, и о влиянии гравитационного поля на сферическую форму Земли они, конечно же, не имели представления. Однако течение рек, движение ледников и многие другие природные процессы, происходившие на Земле, они интуитивно связывали с влиянием Луны. Воздействие магнитного поля Земли, которое создается в результате сложного движения различных компонентов в ядре Земли и с которым тесно связано ее электрическое поле, монгольские народы учитывали при своих традиционных сезонных передвижениях за скотом.

\footnotetext{
${ }^{1}$ Большая Советская Энциклопедия. 3-е изд. М.: Советская Энциклопедия. 1972. Т. 9. С. 476.

2 Там же.
} 
Время в архаическом сознании древних монголов выражалось не только восходом и заходом Солнца и его положением в зените; оно также представлялось в виде особого порядка смены физических состояний: сезонных периодов, многих физических и природных процессов, которые фиксировались народными знаниями и преставлениями. До сих пор рядовой монгол может с точностью до нескольких минут определить время, находясь в юрте, - по движению и нахождению солнечного луча, проникающего в юрту через дымовое отверстие. Мировоззрение кочевника о временных параметрах всегда выстраивалось на основе начальных знаний о многих физических процессах, которые, как отмечает та же кочевая культура, были периодичны и обусловливались вращением Земли вокруг своей оси. При этом кочевая культура как никакая другая имела четкое представление о такой категории времени, как его необратимость. Изначально в устных творческих потенциалах и позже в письменных источниках культура всегда стремилась отметить этот феномен, осознавая и реализуя его в своих этногенетических, космологических и космогенетических мифах. Необратимость времени воспринималась монгольскими народами как сложная система воздействия множества природных систем друг на друга. Так, они отмечали, что прошлое нельзя воспроизвести в реальной жизни - прошлое забывается, если его не зафиксировать посредством сохранения и трансляции потомкам уникальных культурных феноменов и исторических записей. Круг как мифологическая и ритуальная модель мироустройства монгольской этносферы является также распространенным символом и пространственной проекцией космической сферы, Земли, Солнца, шара, колеса, дымового отверстия в юрте (тооно).

Понятие пространства у кочевых культур гораздо сложнее, чем понятие времени. Первые представления о пространстве у монгольских народов возникли из вполне очевидного феномена их передвижения по своим родовым и племенным территориям, которая считалась сакральной и почиталась как таковая. Пространство внутри монголосферы - это также существование в природе определенных физических объектов (земля, горы, озера, реки, деревья и т.д.), в исторически обозримое время ставших объектами почитания. К пространству вокруг себя они относили также и небесную сферу, сакрализуя Солнце, Луну, звезды, созвездия, небесные тела, такие как Полярная звезда (Алтан Гадас), Большая и Малая Медведицы (Долон Убэгэн), Плеяды (Мичит), Венера (Цолмон), Млечный путь (Тэнгэрийн Залгаа). В структуру астральных мифов монгольских народов также было включено и Небо как категория безначальная, а значит бесконечная, несотворенная, владеющая судьбами мира монгольского сообщества и его отдельного индивида. Монголы очень хорошо определяли численные характеристики своего пространства - например, расстояние между объектами и свойства этих расстояний. «Мифологические характеристики пространства, - пишет Н.Л. Жуковская, - следующие: одухотворенность, конкретность (насыщенность материальными предметами), неразрывная слитность с временем, организованность, т.е. членение на составляющие, основанное на двоичной классификации (север - юг, правое - левое, верх - низ и др.), взаимосвязанность с числом, идентичность его освоенной части вселенной (космосу) и противостояние неосвоенному пространству (хаосу)» [Жуковская 1988: 13]. Описывая мифологическое время, Н.Л. Жуковская предупреждает, что «правремя и время первотворения» неизмеримо, но «будучи неизмеримым линейно, оно, тем не менее, замкнуто в циклы и постоянно воспроизводит в календарных обрядах акт первотворения мироздания; благодаря реально повторяющимся календарным циклам время мифологическое и время эмпирическое как бы сосуществуют одновременно 
в разных измерениях, не мешая и не противореча друг другу» [Жуковская 1988: 14].

Буддийская космологическая и космогоническая традиция монгольских народов в результате адаптации буддийской культуры на территории Центральной Азии, естественно, ближе всего по теоретическим и идентификационным признакам к хуннской, древнеиндийской, тибетской и уйгурской традициям. Буддийские космологические теории представляют собой довольно сложную комплексную систему. Для космологических представлений буддийской мифологии характерны широта охвата и стремление умножать все элементы мироздания до бесконечности. Известный буддолог Леннарт Мяль пояснял: «Неисчислимое количество миров группируется в огромные мировые системы (сахалока), которых, по образному сравнению из буддийских текстов, больше, чем песчинок в реке Ганг. Каждый отдельный мир представляет собой плоский диск земли, он лежит на воде, та покоится в воздухе, а воздух - в пространстве. В центре мира стоит огромная гора Меру (Сумеру), вокруг которой вращаются солнце, луна и звезды. Меру окружают концентрически семь горных хребтов (они отделены друг от друга кольцевидными озерами). За ними расположены четыре континента: на востоке - Пурвавидеха, на юге - Джамбудвипа, на западе - Апарагодана, на севере - Уттаракуру» ${ }^{1}$. При этом наиболее интересным феноменом, с точки зрения автора данной статьи, является мир, именуемый Джамбудвипой, где у людей жизненный срок самый короткий по сравнению с остальными тремя, но самый счастливый. Люди, рожденные в этом мире, отличаются мужеством, умом и благочестием. Продолжительность жизни миров в буддийских космогенетических мифах исчисляется большой (великой) «кальпой», имеющей четыре раздела: кальпа созидания, где миры возникают; кальпа продолжения, где живут и поддерживают жизнь разумные существа; кальпа исчезновения, где все исчезает в последнем огне; завершающая кальпа, где нет ничего, кроме пустого пространства. Эти процессы создания, продолжения и разрушения происходят снова и снова, повторяясь до бесконечности в течение бесконечного времени. «Эта связь пространства и времени с неисчислимыми мирами является ареной для сансары, “циклического существования"», - утверждает Реджинальд А. Рей [Рей 2004: 28]. В буддийских мифологических представлениях сансара - это циклическое бытие и бесконечные перерождения индивида, противопоставленные феномену нирваны. Сансара в представлениях рядового мирянина - это реальный мир их пребывания в профанном мире, вера в непрерывную цепь перерождений, что, согласно буддийским теориям и практикам, является источником страдания. В мифологических аспектах безначальной сансары существуют пять миров в контексте «пяти реальностей» (путей). Это пять перерождений: в мире божеств, мире людей, мире животных, мире претов (голодных духов), мире «адских» существ.

В мифологемах космогонического характера монголосферы, многочисленные племена которой в различные хронологические периоды адаптировали буддийскую культуру, присутствует феномен сакрализации некоей территории, которая выступает как Шамбала. Разве что ленивый не писал о некой таинственной стране, где благоденствует все живое. В славянских традициях, например, - это мифическое Беловодье, в тюрко-алтайской традиции это место имеет много различных наименований. В традиционной буддийской интерпретации практически всех школ буддизма Шамбала - это находящаяся в другом измерении страна, насельники которой высокоразвиты, и именно там процве-

\footnotetext{
1 Мяль Л. Буддийская мифология. - Мифы народов мира: энциклопедия. В 2 т. М.: Советская Энциклопедия. 1991. С. 191.
} 
тает учение Калачакры. Ю.Н. Рерих резюмирует, что «сокровенное Учение буддистов Монголии и Тибета о Шамбале» в центральноазиатской махаяне имеет двоякое значение: в символическом смысле - это олицетворение времен грядущей правды, победы над злом, человеческого совершенства, век истины и единства человечества, господства истинного учения Будды, век Майтрейи. В конкретном смысле Шамбала - потаенное место пребывания в Центральной Азии общины великих «держателей» и «носителей» мира - владыки и его сподвижников - махатм [Рерих 1982: 296].

Общие фундаментальные понятия, категории и символы классической формы буддизма, в т.ч. и феномен Земли, идеи сансары и Шамбалы, распространившиеся среди монгольских народов, естественно, нашли отражение в существующих на сегодняшний день религиозных реалиях монгольской этносферы. Будучи основными формами и главными организующими структурами в религиозной культуре, буддийские мифологемы, как правило, воспроизводят конкретные свойства и отношения универсального бытия и универсального познания в наиболее сакральной и концентрированной форме.

В заключение хотелось бы отметить, что конфессиональная идентичность монгольских народов, основанная на синтезе собственных традиционных религиозных идей и практик с буддийской теорией и практикой, в современный период сама по себе является реальным феноменом, сохраняющим и транслирующим уникальность своих этнокультурных традиций.

Работа выполнена в рамках государственного задания ИМБТ СО РАН по проекту ХІІ.191.1.3. «Комплексное исследование религиозно-философских, историкокультурных, социально-политических аспектов буддизма в традиционных и современных контекстах России и стран Центральной и Восточной Азиџ», номер госрегистрации № AAAA-A17-117021310263-7.

\section{Список литературы}

Абаева Л.Л. 2017. Символы буддийской культуры в историко-культурном измерении и современных социально-политических процессах монгольского мира. - Власть. № 5. С. 130-136 .

Жуковская Н.Л. 1988. Категории и символика традиционной культуры монголов. М.: Наука. 194 с.

Крамер С.Н. 1977. Мифология Шумера и Аккада. - Мифологии древнего мира. М.: Главная редакция восточной литературы изд-ва «Наука». С. 122-161.

Мифологии древнего мира. 1977. М.: Главная редакция восточной литературы изд-ва «Наука». 455 с.

Рей Р. 2004. Нерушимые истины. М.: АСТ-Астрель. 511 с.

Рерих Ю.Н. 1982. По тропам Срединной Азии. Хабаровск: Хабаровское книжное изд-во. 304 с. 
ABAEVA Liubov' Lubsanovna, Dr.Sci. (Hist.), Professor; Principal Researcher of the Department of Philosophy, Cultural Anthropology and Religious Studies, Institute of Mongolian, Buddhist and Tibetan Studies, Siberian branch of Russian Academy of Sciences (6 Sakh'yanovoj St, Ulan-Ude, Republic of Buryatia, Russia,670047; luba-abaeva@mail.ru

\title{
EARTH PHENOMENON IN THE CONTEXT OF TRADITIONAL RELIGIOUS VIEWS OF THE MONGOLIAN PEOPLE IN THE VECTOR OF ADAPTATION OF THE BUDDHIST THEORIES AND PRACTICES: A COMPARATIVE ANALYSIS
}

\begin{abstract}
The article on the material of the Mongolian people considers the phenomenon of Earth as a mythogenic, mythopoetic and world outlook image, which is fixed first in their cosmogonic and cosmogenetic representations recorded in the frame of reference both on objective and on subjective worlds. The cosmogonic representations of the Mongolian people first reflect synchronous aspects of their ideas on the structure of the world, its device, its interrelations and functions. The cosmogonic and cosmogenetic myths of the Mongolian people, as well as of other ethnic cultures, are more diachronic as concentrate on the general idea of emergence of the Universe, its uniqueness, evolution and also on problems of space and time, geogenesis, anthropogenesis, origin of flora and fauna. In the context of the cosmogenetic representations the myth about the dual organization of the Sky and Earth (Tenger-Gazar of delkhiy, Umay) is the most popular and characteristic. The author mentions also some Buddhist ideas and practices in relation to the phenomenon of Earth.

Keywords: phenomenon of Earth, Mongolian people, traditional cosmogonic and cosmogenetic representations, Buddhist discourses, comparative analysis
\end{abstract}

ПАСАНДИДЕ Сомайе (Иран) - соискатель кафедры политологии и политического управления Российской академии народного хозяйства и государственной службы при Президенте РФ (119571, Россия, г. Москва, пр-кт Вернадского, 84, корп. 9; somayeh_pasandide@yahoo.com)

АСОНОВ Николай Васильевич - доктор политических наук, профессор кафедры политологии Московского педагогического государственного университета (119991, Россия, г. Москва, ул. Малая Пироговская, 1, стр. 1; nbassonov@yandex.ru)

\section{МАРКСИЗМ В ИСЛАМСКОЙ ПОЛИТИЧЕСКОЙ МЫСЛИ}

Аннотация. В статье раскрывается специфика постепенного осмысления марксизма в исламской политической мысли как отклика на несправедливость и насилие, идущие с Запада и разрушающие нравственные устои мусульман под видом утверждения буржуазной демократии. Так как буржуазия никогда не откажется от своего права на политическое и экономическое господство над миром, учение Маркса способно найти в исламе, как и в других гуманистических конфессиях, своего союзника и обрести новые интерпретации, отвечающие духу времени и национально-государственным традициям.

Ключевые слова: политическая мысль ислама, джихад, марксизм, коммунизм, капитализм, государСтво, власть

$\Pi$ ринято считать, что марксизм как политическое учение нашел отклик только на Западе, т.к. с самого начала представлял собой анализ тех изменений, которые произошли в Европе и Америке в Новое время. Это правильно, но именно в ту пору Запад стал навязывать исламскому миру свою волю и распространять на него свою систему ценностей. В результате Восток с XX в. начал 